\title{
DEGREE OF GRAMMATICALISATION OF BEHIND, BENEATH, BETWEEN AND BETWIXT IN MIDDLE ENGLISH
}

\section{EWA CISZEK-KILISZEWSKA}

Adam Mickiewicz University in Poznań

ewac@wa.amu.edu.pl

\begin{abstract}
The present paper traces the history of four selected adverbs with the prefix $b e$ - in Middle English. Already in Old English behind, beneath, between and betwixt are attested to function as both adverbs and prepositions, which demonstrates that the process of grammaticalisation accounting for the development of prepositions from adverbs started before that period. The focus of the study are the diachronic changes of the degree of grammaticalisation of the examined lexemes in the Middle English period as demonstrated by the ratio of their use with a respective function in the most natural context. Hence, specially selected Middle English prose texts are analysed.

The analysis shows that while behind and beneath are still frequently used as adverbs in the whole Middle English period, between and betwixt are predominantly used as prepositions already in Early Middle English. This clearly demonstrates that the degree of grammaticalisation of the latter two Middle English words was much higher than that of behind and beneath.
\end{abstract}

Keywords: adverb, grammaticalisation, Middle English, preposition

\section{Introduction}

The aim of the present paper is to investigate the history of four selected compound adverbs with the prefix $b e$ - in Middle English from the perspective of the degree of grammaticalisation. The analysed lexemes share some structural, functional, etymological and semantic characteristics and include behind, beneath, between and betwixt, i.e., ME bihīnde(n), binēthe(n), bitwēne and bitwix(en). Structurally, these words are composed of the prefix be-, ME $b i$-/beand an adverb or a numeral, and are recorded in the function of both prepositions and adverbs already in Old English. All the examined compound adverbs have emerged in the process of grammaticalisation, specifically reanalysis of the preposition and adverb $b \bar{\imath}$ (big) 'about', which developed into the prefix $b i$-/be-, and respective adverbs with the originally locative sense. Further, the grammaticalisation continued, which is demonstrated by the rise of grammatical units, i.e., prepositions from lexical ones, i.e., adverbs. As confirmed by the presence of the discussed words functioning as prepositions in Old English, those two stages of grammaticalisation must have occurred before that period. The focus of the study is the Middle English period and the diachronic changes of the degree 
of grammaticalisation of ME bihinde(n), binèthe(n), bitwēne and bitwix(en). The degree will be tested on the basis of the ratio of their use with a respective function. The decrease in the adverbial use of the lexemes will be a sign of a higher degree of grammaticalisation.

\section{Theoretical framework and methodology}

The grammaticalisation framework applied in the study relies on the classical definition by Kuryłowicz (1965: 69) stating that "[g]rammaticalization consists in the increase of the range of a morpheme advancing from a lexical to a grammatical or from a less grammatical to a more grammatical status, e.g., from a derivative formant to an inflectional one" as well as on the more recently view of grammaticalisation as "the process whereby lexical items and constructions come in certain linguistic contexts to serve grammatical functions, and, once grammaticalized, continue to develop new grammatical functions" (Hopper and Traugott 2003: xv).

The special context in which the degree of grammaticalisation of bihinde(n), binêthe(n), bitwēne and bitwix(en) will be examined is intended to be the most natural, or neutral, i.e., closest to spoken Middle English. Hence, the selection of special prose texts for the analysis will guarantee the exclusion of occurrences which might have been motivated by such poetic devices as rhyme, rhythm or alliteration. As noticed by Markus, "prose, on an average, employed a language less stylised than verse and was, thus, relatively close to the language really used by people." (http://www.uibk.ac.at/anglistik/projects/icamet/) The linguistic material selected for the present investigation relies on the recent achievements of corpus linguistics and specifically on Manfred Markus's (2010) Innsbruck Corpus of Middle English Prose ${ }^{1}$ (henceforth Innsbruck Corpus). This extensive electronic corpus is a collection of complete texts, not of text samples, which ensures the completeness of the analysed data. However, not all the 129 texts amounting to as many as c. 7.8 million words have been employed in the present study. The intention is to analyse the behaviour of bihinde(n), binēthe(n), bitwēne and bitwix(en) only in the texts with most reliably identified localisation and dates, the information of which has been derived from A Linguistic Atlas of Early Middle English (LAEME) and an electronic version of A Linguistic Atlas of Late Mediaeval English (eLALME) (cf. Esquibel and Wojtyś 2012; Wełna 2013, 2015). Such a procedure will guarantee the highest accurateness and reliability of the obtained results relating to the chronological and dialectal distribution of the examined lexemes. Thus, a total number of 56 Middle English complete prose texts will be subject to further analysis. The Early Middle English material consists of 21 texts (599,583 words) and the Late Middle English one of 35 texts

\footnotetext{
I hereby gratefully acknowledge the Innsbruck Corpus of Middle English Prose (version 2.4) to its compiler, Professor Manfred Markus from the University of Innsbruck.
} 
$(1,900,729$ words). Altogether, the study is based on about 2.5 million words. Other extensive and acknowledged databases employed for the analysis include the Oxford English Dictionary online (henceforth OED), the Middle English Dictionary online (henceforth MED) as well as the Dictionary of Old English (A$\mathrm{H}$ online) (henceforth DOE) and the Dictionary of Old English Corpus (DOEC).

\section{Previous studies on the grammaticalisation of Medieval English adverbs}

Middle English adverbs and their development into prepositions and conjunctions/subordinarors viewed in the grammaticalisation framework have been recently of interest to a few scholars. Molencki, Rissanen and KahlasTarkka, who performed detailed qualitative studies richly illustrated with quotations from various corpora and dictionaries, deserve a special mention here.

Molencki studied the topic most extensively. Molencki (2003, 2005, 2007abc, 2008) offers a detailed analysis of ME as, after, before, since, because and their path of development from adverbs to conjunctions. Moreover, he investigates a group of Middle English prepositions and conjunctions borrowed from Romance sources, e.g., according to, during, purveyed/provided, save, except, maugre, (a)round and sans (Molencki 2011a). Molencki (2011b) discusses the development of the preposition forward in Middle English. He bases his studies on the $D O E C$, the $O E D$ and the $M E D$. Moreover, in his extensive book devoted to the rise of Medieval English causal conjunctions in the process of grammaticalisation Molencki (2012) thoroughly discusses the development of because from the noun cause. The author employs not only the databases mentioned above but also the Corpus of Middle English Poetry and Prose, the Anglo-Norman Dictionary and the Helsinki corpora.

Rissanen (2000a and 2004) studies the grammaticalisation of according to and beside(s) respectively, relying mainly on the Medieval English parts of the Helsinki Corpus and the ARCHER Corpus. Rissanen (2005) investigates the development of the Early English till and until into conjunctions and Rissanen (2007) discusses the replacement of the Old English preposition and subordinator $o p$ by Old Norse till. The latter study relies on Old and Middle English samples from the Helsinki Corpus as well as on the DOEC and the Middle English Compendium.

Kahlas-Tarkka (2010) describes Old and Middle English low frequency temporal expressions consisting of the prepositions in, at, to or till, the noun time and the particle pe. Her data are retrieved from the Helsinki Corpus and, similarly to Molencki's studies, from the $D O E C$ and the $O E D$.

Additionally, Iglesias-Rábade (2011) examines twelve Middle English prepositions, i.e. aboue, after, at, bi, bifore, bihinde, biside, in, on, ouer, purgh and under. Relying on the occurrences recorded in the Middle English part of the Helsinki Corpus he analysed the development of these prepositions from lexical items as well as their semantic erosion. Moreover, he conducts the analysis of the 
frequency and dialectal distribution of the prepositions, which, however, due to the size of the corpus may pose the question of the reliability of his results.

ME bihinde(n), binēthe(n), bitwēne and bitwix(en) have not been investigated in the grammaticalisation framework so far. Some aspects of those lexemes have been of interest to a couple of scholars, though. Hotta (2014) analyses recorded spelling variants of ME betwixt and between and the competition between them. Ciszek-Kiliszewska (2014) compares the semantics of ME twène and bitwēne and provides the textual distribution of bitwēne and bitwix(en) in texts employing twēne. Moreover, Ciszek-Kiliszewska (2017a) investigates the semantic features as well as the temporal, textual and dialect distribution of ME bitwix(en).

Ciszek-Kiliszewska (2017b) thoroughly discusses various aspects of bihïnde(n), binēthe(n), bitwēne and bitwix(en) as well as biföre(n) and biyōnd(e) relating to the use of those lexemes in complete Middle English prose texts. The author devotes a considerable part of her book to the semantic analysis of the analysed words, including the distinction between their prepositional and adverbial uses. Ciszek-Kiliszewska recognises the prototypical locative senses, the temporal and the abstract/metaphoric (neither locative nor temporal) senses. She also provides the textual and dialectal distribution of the analysed words accompanied by their frequencies. In terms of the obtained detailed quantitative results, the study is intended to provide a reliable overview of the use of the examined lexemes in specific periods, dialects and texts as well as a comprehensive database for further studies. Hence, the author does not distinguish between the frequencies of the prepositional and of the adverbial uses of the words in particular texts. Ciszek-Kiliszewska (2017) will serve as a source of some data and a point of reference for the present paper, which delves into the frequencies and the proportions between prepositional and adverbial uses as well as the degree of grammaticalisation of the four ME $b i$ - words analysed there.

\section{Etymology}

The $M E D$, the $O E D$ and the $D O E$ point to $\mathrm{OE}$ bi-, behindan (see DOE behindan) as the ancestor of ME bihinde(n). Regarding the structure of OE behindan, the $O E D$ recognises the word as composed of the Germanic prefix be-and the adverb hindan 'from behind, behind', specifying the direction. The adverb goes back to the root hind-found in words like hinder and hindmost and the adverbial suffix ana. The prefix be-adds the meaning relating to the location. As mentioned above, the same prefix appears in all the words analysed in the present study.

ME binethe(n) is recognised by the MED and the $O E D$ as going back to OE bineopan, -nipan (see DOE beneopan). Moreover, the OED's claim that "[o]riginally an adverb, but already in Old English construed with dative (of reference), as a preposition" may point to the grammaticalisation path. Be-niðan/neoðan is analysed as consisting of the prefix be-and niðan, neoðan 
'below, down', originally 'from below,' earlier neoðane, neoðone; cf. OS nithana, OHG nidana, MHG niden(e) < Gmc nipar 'lower, farther down, down' plus the adverbial ending -ana.

As claimed by the $M E D$, the ME bitwēne originates in $\mathrm{OE}$ betwèonum, -an $\& \operatorname{bitwin}(u m)$. The $O E D$ provides a similar origin, yet the dictionary distinguishes two related Old English forms, i.e., OE bi-, betwēonum, etc., which developed into Middle English bitwenen, -twene, and the exclusively Northern OE bi-, betwēon, etc., which evolved into ME bitwēn. "[A]fter 1400, when final $-e$ became mute, and was omitted in writing, or retained only as a sign of a preceding long vowel, both forms necessarily coalesced in betwene (= betwèn)". Additionally, the OED recognises OE betwēonum as originating in the Old English construction bi sēm tweenonum, lit. 'by seas twain', in which twēonum is derived from the original Old English dative plural *twīhnum, *tweohnum ${ }^{2}$. Phrases like frið freondum bi twēon 'peace friends between' represent the further step towards the merger of the preposition $b i$ and twēonum/twēon. Regarding the early forms of between, the $D O E$, which, similarly to the $M E D$ and the $O E D$, identifies the Old English preposition and adverb betwēonan as the ancestor of Middle English bitwēne, "here are all forms derived from be + tweonum (dat.) with medial $-n$-, and all forms derived from be + *twīhn (acc.) with final -n, -nh." (DOE betwēonan)

ME bitwix(e), the ancestor of Present-Day English betwixt, is claimed by the $M E D$ to be going back to OE betwix,-tweox, -twux(t), -tux (cf. OFris. twiska, OS twisk). Likewise, according to the OED, ME bitwix goes back to $\mathrm{OE}$ betweohs, -tweox, -twux, -twyx, -tux, probably shortened from the dative *be-tweoxum, -tweox(a)n, preserved in Middle English as be-, bitwixe(n). OE *be-tweoxum, -tweohsum, originally $\mathrm{OE} *$ bi-twihsum $<*$-twicsum, *-twiscum is viewed as composed of the prefix be- and *twiscum, (dative plural of *twisc 'two-fold', adj.) (OS twisc, OHG zuiski, MHG zwisc, zwisch < OGerm. twiskjo-). *twisc can be further analysed as a complex form consisting of twa 'two' and the suffix -isc. The Old English ancestor of ME bitwix(en) provided by the DOE is the preposition and adverb betwux. The Old English forms authorized by the dictionary include "all forms derived from be + Gmc. *twisk- with final $-x$, $-x h,-x s,-x t,-h s,-h x$, or an $-(a) n$ suffix and medial $-x-,-h x-. "$ (DOE betwux)

\section{Grammaticalisation}

The test demonstrating the degree of grammaticalisation of the examined Middle English words, bihinde(n), binethe(n), bitwène and bitwix(en), conducted in the present study will rely on the proportion of the use of those lexemes with different functions. Specifically, the number of tokens of adverbial uses of respective words will be compared to the number of tokens of prepositional uses attested in the

2 *twīhnum can be further analysed as twīh + the collective suffix $-n-+$ case inflection (Kitson 1993: 12). 
examined specially selected Middle English prose texts. The ratios will be tested separately for Early and Late Middle English texts. This will allow us for the observation of some diachronic tendencies concerning the use of bihinde(n), binèthe(n), bitwēne and bitwix(en). The textual and dialectal distribution of the examined tokens is presented in the hope of providing some insight into the degree of grammaticalisation as perceived from those perspectives.

\subsection{Grammaticalisation of bihīnde(n)}

As evaluated by Ciszek-Kiliszewska (2017: 109), the examined 56 complete Middle English prose texts specially selected from the Innsbruck Corpus amounting to c. 2.5 million words contain 239 occurrences of bihinde(n). Table 1 shows the distribution of numbers recorded in Early and Late Middle English prose texts.

Table 1. The tokens of bihinde(n) in Middle English prose

\begin{tabular}{|c|c|c|c|}
\hline Period & Number of all words & Number of tokens & $\begin{array}{c}\text { Relative frequency } \\
\text { per 100,000 words }\end{array}$ \\
\hline EME & 599,583 & 50 & 8.34 \\
\hline LME & $1,900,729$ & 189 & 9.94 \\
\hline ME & $2,500,312$ & 239 & 9.56 \\
\hline
\end{tabular}

The relative frequency per 100,000 words shows that despite the uneven number of tokens in the texts representing the two Middle English subperiods, the relative use of bihinde(n) is similar in both Early and Late Middle English.

Regarding the Early Middle English period, the investigation of the texts shows the use of bihinde( $n$ ) in only about a half of them. Table 2 (in the Appendix) presents the distribution of the tokens in specific Early Middle English prose texts divided into groups representing particular dialects. Moreover, the instances are divided according to their function, i.e., adverbs and prepositions.

In total, bihinde(n) is recorded 35 times as an adverb and only 15 times as a preposition in the investigated Early Middle English texts. Figure 1 presents the absolute number of tokens of the adverbs and prepositions normalised to a relative frequency per 100,000 words. 


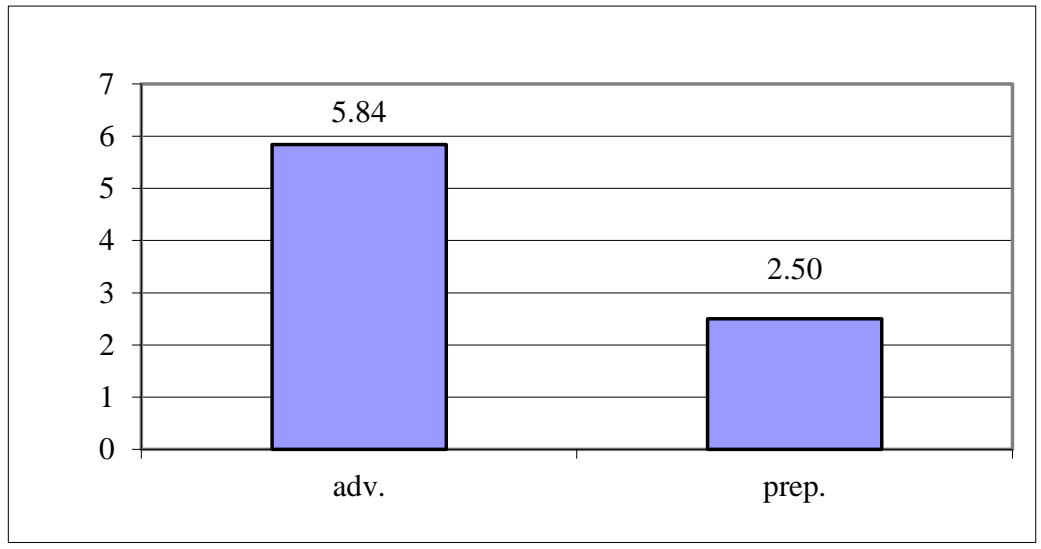

Figure 1. Early Middle English bihīnde(n): relative frequency per 100,000 words

The general dominant function of bihinde( $n$ ) as an adverb in the examined linguistic material can be easily seen. Moreover, the same tendency is exhibited in all the dialects and in the analysed prose texts including bihinde(n). A minor exception is the text of Ancrene Riwle (Gon-Ca) in which the use of the adverbial and prepositional tokens is balanced.

The analysis of the Late Middle English prose texts demonstrates a radically different distribution of bihinde(n). Generally, more tokens than in Early Middle English are recorded and almost all Late Middle English texts employ bihinde(n). Table 3 (in the Appendix) presents the results of the investigation.

The total absolute numbers demonstrate that the function of bihinde(n) notably changes in Late Middle English. The lexeme is attested to function as a preposition more frequently than as an adverb. Figure 2 presents those frequencies as relative per 100,000 words.

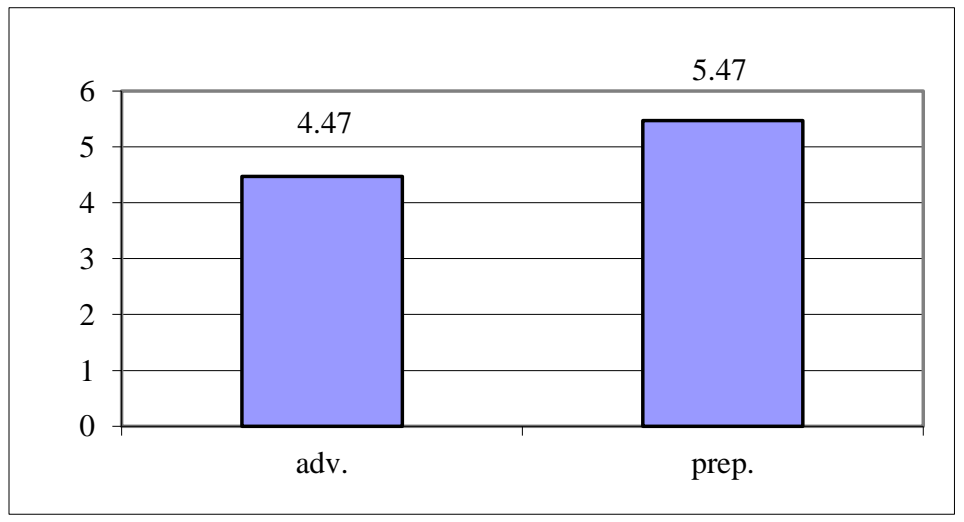

Figure 2. Late Middle English bihinde(n): relative frequency per 100,000 words 
Figure 3 sets the data from Figures 1 and 2 together and demonstrates the changes in the frequencies of adverbs and prepositions between the Early and Late Middle English prose.

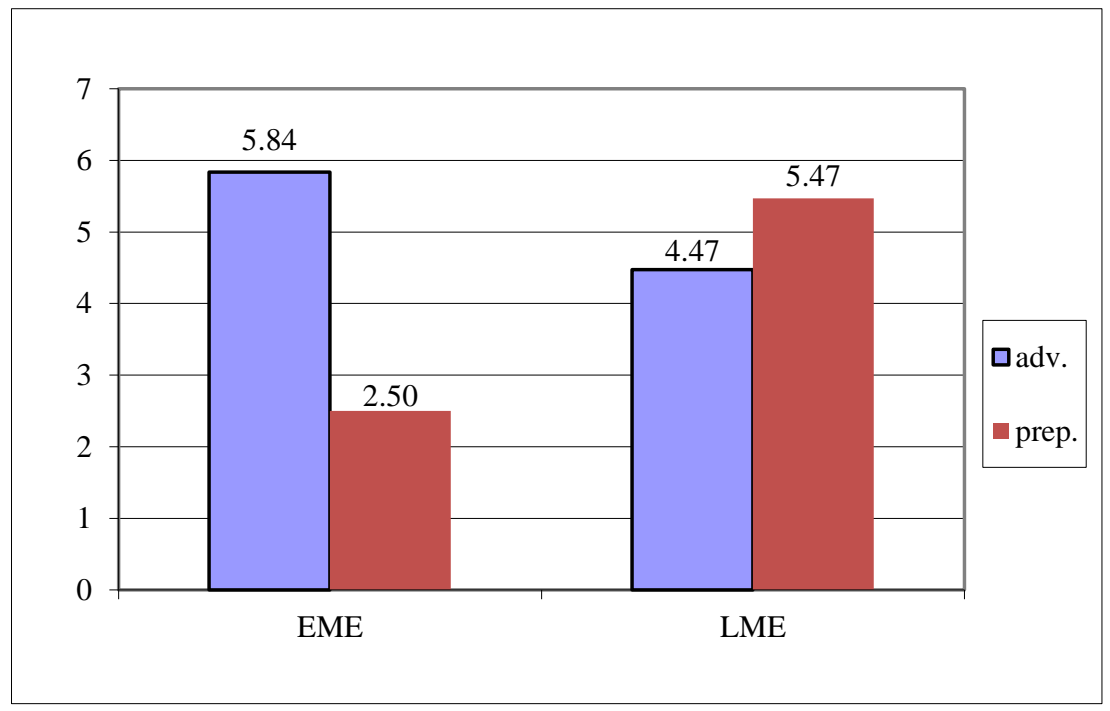

Figure 3. Early and Late Middle English bihinde(n): relative frequency per 100,000 words

While the frequency of use of bihinde(n) as an adverb shows a tendency towards a decrease in the later period, the prepositional function of bihinde(n) is employed noticeably more frequently in Late than in Early Middle English. The prevailingly adverbial use of bihinde( $n$ ) in Early Middle English with time changes into a more balanced use of the word with both functions with a slightly higher frequency of bihinde(n) employed as a preposition in Late Middle English. Thus, it might be assumed that ME bihinde(n) shows an advancing yet still intermediate degree of grammaticalisation. Interestingly, a scrutiny of the dialectal and textual distribution of bihinde(n) in Early and in Late Middle English reveals that while the EM micro-scale use overlaps with the global results obtained for Early Middle English, there are some discrepancies in Late Middle English. Specifically, one out of four West Midland texts, the only Kentish text and 11 out of 16 East Midland texts exhibit proportions of the adverbial and the prepositional use of bihinde(n) different from those observed for the whole LME period. The adverbial use of bihinde(n) in them is either higher or the same as the prepositional one, which exhibits a lower micro-scale degree of grammaticalisation than that estimated for Late Middle English prose. 


\subsection{Grammaticalisation of $\operatorname{binēthe(n)}$}

The examined Middle English prose texts of c. 2.5 million words include 75 instances of binēthe(n) (Ciszek-Kiliszewska 2017: 130). Table 4 shows the distribution of tokens attested in Early and Late Middle English prose.

Table 4. The tokens of binēthe(n) in Middle English prose

\begin{tabular}{|c|c|c|c|}
\hline Period & $\begin{array}{c}\text { Number of all } \\
\text { words }\end{array}$ & Number of tokens & $\begin{array}{c}\text { Relative frequency per } \\
\mathbf{1 0 0 , 0 0 0} \text { words }\end{array}$ \\
\hline EME & 599,583 & 26 & 4.34 \\
\hline LME & $1,900,729$ & 49 & 2.58 \\
\hline ME & $2,500,312$ & 75 & 3.00 \\
\hline
\end{tabular}

The relative frequency per 100,000 words shows that despite the uneven number of tokens in the texts representing the two Middle English subperiods, the relative use of binethe(n) is similarly low in both Early and Late Middle English.

Binethe(n) can be found in about a half of the analysed Early Middle English texts. Nevertheless, texts representing all the dialectal areas employ the lexeme. Table 5 (in the Appendix) presents the distribution of tokens according to the syntactic function.

The obtained results show that the adverbial function of binethe(n) is represented by a higher number of occurrences, i.e., 17 than the prepositional one attested in 9 cases. Figure 4 presents the absolute number of the adverbs and prepositions normalised to a relative frequency per 100,000 words.

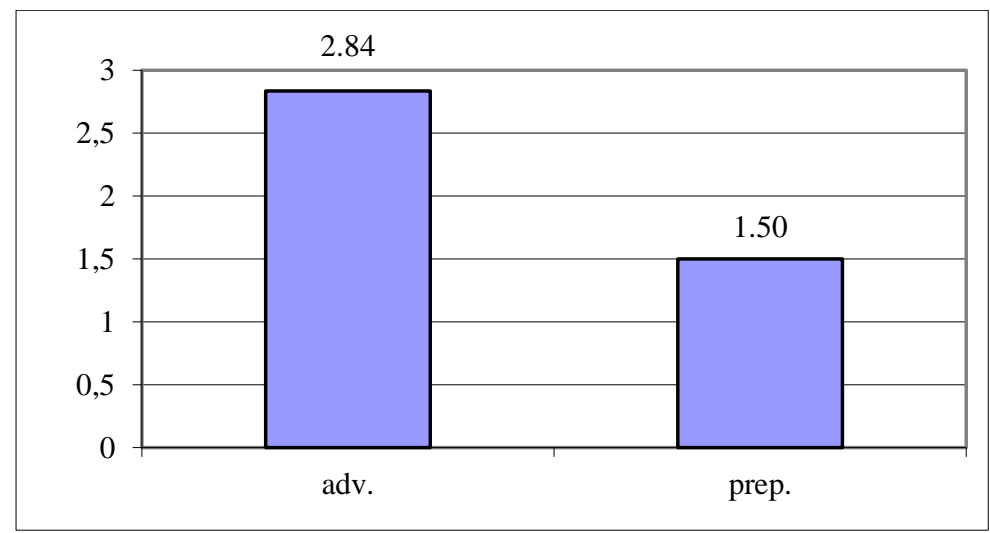

Figure 4. Early Middle English binēthe(n): relative frequency per 100,000 words 
Figure 4 clearly demonstrates that the adverbial function of binethe(n) is employed about twice as frequently as the prepositional function in Early Middle English prose. Hence, it can be concluded that the degree of grammaticalisation of binethe(n) in Early Middle English is low. When the same phenomenon is observed from the perspective of specific dialects or single prose texts, generally, a similar conclusion can be drawn. There are, however, some Southern and West Midland texts which exhibit minor deviation from the overall tendency (cf. Table 5).

The investigation of the Late Middle English prose texts demonstrates a higher number of attested tokens of binethe $(n)$ in comparison to the Early Middle English linguistic material. Table 6 (in the Appendix) illustrates the results of the analysis including the textual distribution of the occurrences with a respective function.

The total absolute numbers of binethe(n) divided according to the function of the lexeme show a similar tendency to that exhibited in Early Middle English prose. Specifically, binetthe(n) is employed as an adverb about twice as frequently as with the prepositional function. Figure 5 presents the proportion of the relative frequencies normalised to the number of instances per 100,000 words.

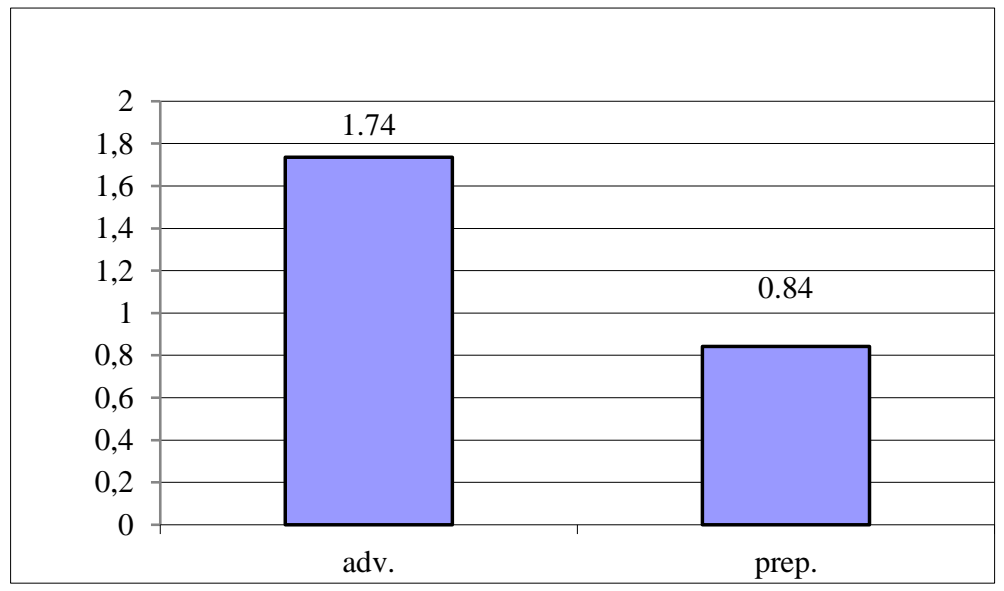

Figure 5. Late Middle English binēthe(n): relative frequency per 100,000 words

Figure 6, combining the data from Figures 4 and 5, illustrates the changes in the frequencies of the adverbial and prepositional functions between Early and Late Middle English prose. 


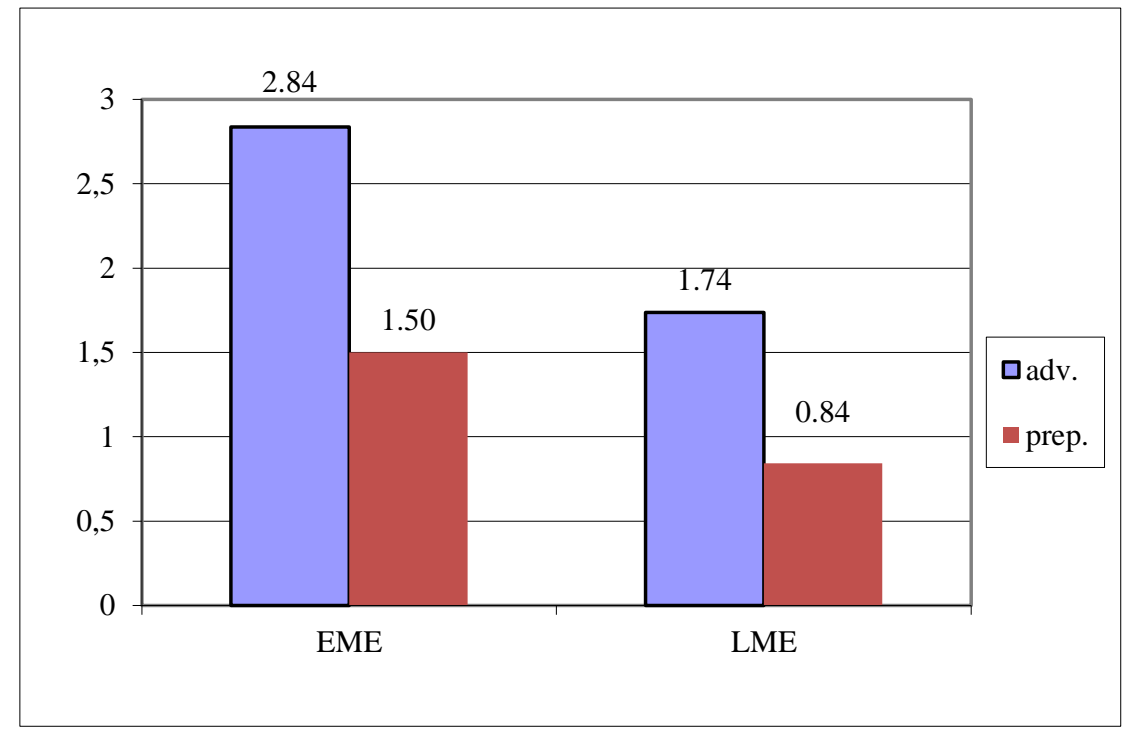

Figure 6. Early and Late Middle English binèthe(n): relative frequency per 100,000 words

The frequency of use of binethe(n) with both functions decreases in Late Middle English. The ratio of the relative frequency reduction is similar in both cases and amounts to about $40 \%$ each. Hence, binèthe (n) becomes employed less frequently in general and its function stays stable in both Early and Late Middle English. In both examined subperiods binethe(n) functions as an adverb about twice more frequently than as a preposition. Consequently, it may be argued that even though ME binêthe(n) is grammaticalised to the extent that it can function not only as an adverb but also as a preposition already in Old English, the degree of its grammaticalisation in Middle English seems low because the lexeme exhibits a tendency towards functioning prevailingly as an adverb both in Early and in Late Middle English. However, a detailed examination of the dialectal and textual distribution of binethe( $n$ ) in Early and in Late Middle English reveals that all the EME Southern texts and some West Midland texts employing binēthe(n) (see Table 5) as well as some LME West Midland (one out of two), Southern (the only one) and East Midland (four out of 12) texts including binèthe(n) (see Table 6) slightly deviated from the general tendency and thus the generally low degree of grammaticalisation. This might be indicative of the dialectal and textual variation with respect to that specific examined lexeme. Moreover, one might speculate that the listed dialects and texts are the leaders initiating and signalling the presupposed change towards a higher degree of grammaticalisation of binêthe(n) in Early Modern English. 


\subsection{Grammaticalisation of bitwēne}

There are 829 instances of bitwene in the investigated Middle English prose texts (Ciszek-Kiliszewska 2017: 150). Table 7 presents their distribution in Early and Late Middle English prose.

Table 7. The tokens of bitwène in Middle English prose

\begin{tabular}{|c|c|c|c|}
\hline Period & $\begin{array}{c}\text { Number of all } \\
\text { words }\end{array}$ & Number of tokens & $\begin{array}{c}\text { Relative frequency per } \\
\mathbf{1 0 0 , 0 0 0} \text { words }\end{array}$ \\
\hline EME & 599,583 & 181 & 30.19 \\
\hline LME & $1,900,729$ & 648 & 34.09 \\
\hline ME & $2,500,312$ & 829 & 33.15 \\
\hline
\end{tabular}

The relative frequency per 100,000 words shows that despite the uneven number of tokens in the texts representing the two Middle English subperiods, the relative use of bitwēne is similar in both Early and Late Middle English.

Regarding the analysed Early Middle English prose texts, bitwēne can be found in all the dialectal areas but not in all texts representing them. Table 8 (in the Appendix) shows the textual and dialectal distribution of tokens according to their syntactic function.

Table 8 shows that there are only seven instances of the adverbial use of bitwēne in the examined complete prose texts of c. 600,000 words. Figure 7 normalises the obtained results to a relative frequency per 100,000 words. In that context, the adverbial function of bitwēne proves to be only slightly more frequent than one token per 100,000 words. The prepositional function of bitweene is employed c. 25 times more frequently.

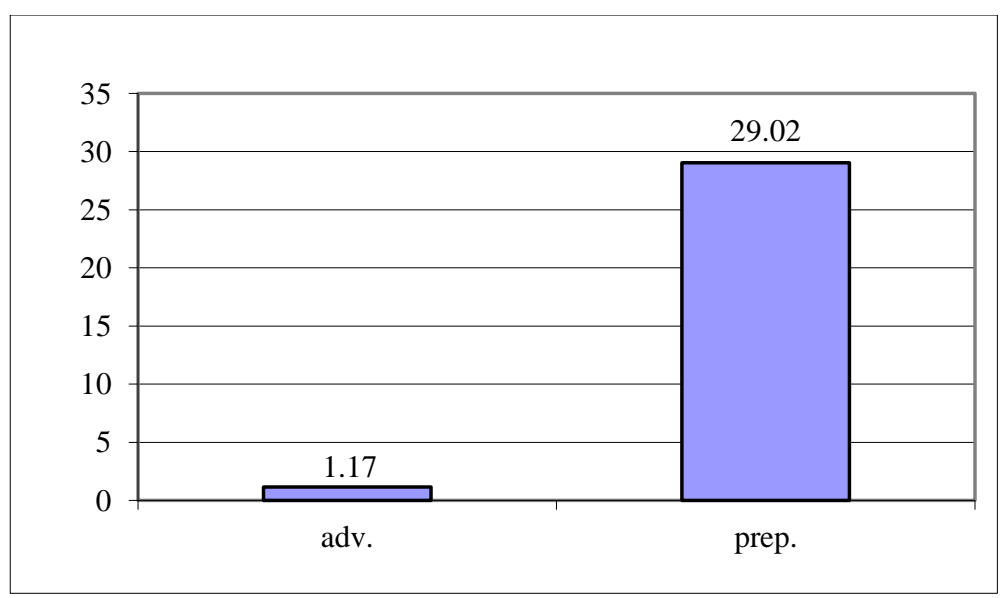

Figure 7. Early Middle English bitwēne: relative frequency per 100,000 words 
Regarding the Late Middle English prose, there are generally more recorded cases of bitweene. Table 9 (in the Appendix) introduces their distribution and functions before the data normalisation.

The table demonstrates that the use of bitwene with the adverbial function in the Late Middle English prose is only sporadic. The dominating function of ME bitwēne is that of a preposition. Figure 8 presents the Late Middle English data normalised to the relative frequencies per 100,000 words. As can be seen bitwēne functioning as an adverb is attested less frequently than once per 100,000 words.

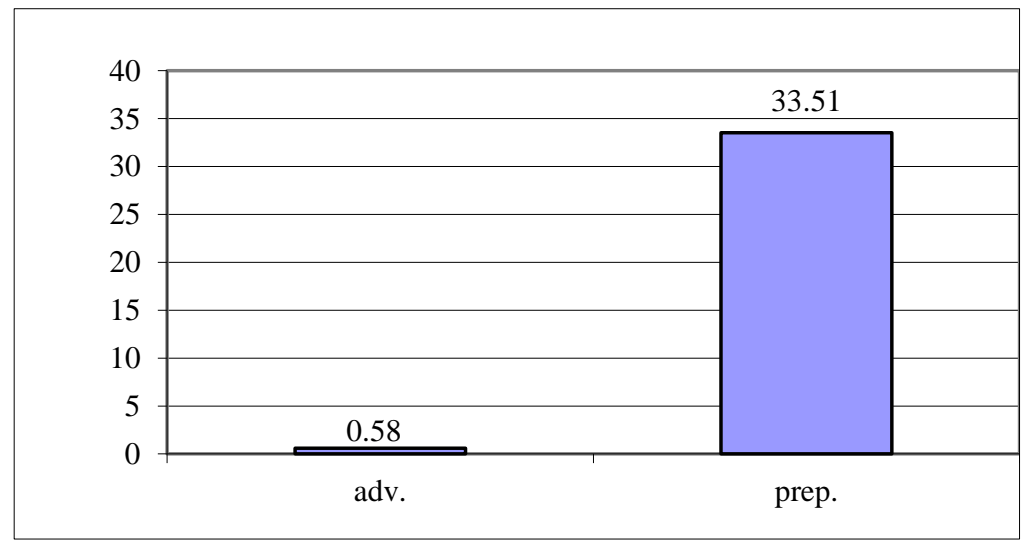

Figure 8. Late Middle English bitwēne: relative frequency per 100,000 words

Figure 9 shows the combination the Early and Late Middle English normalised data relating to bitwēne.

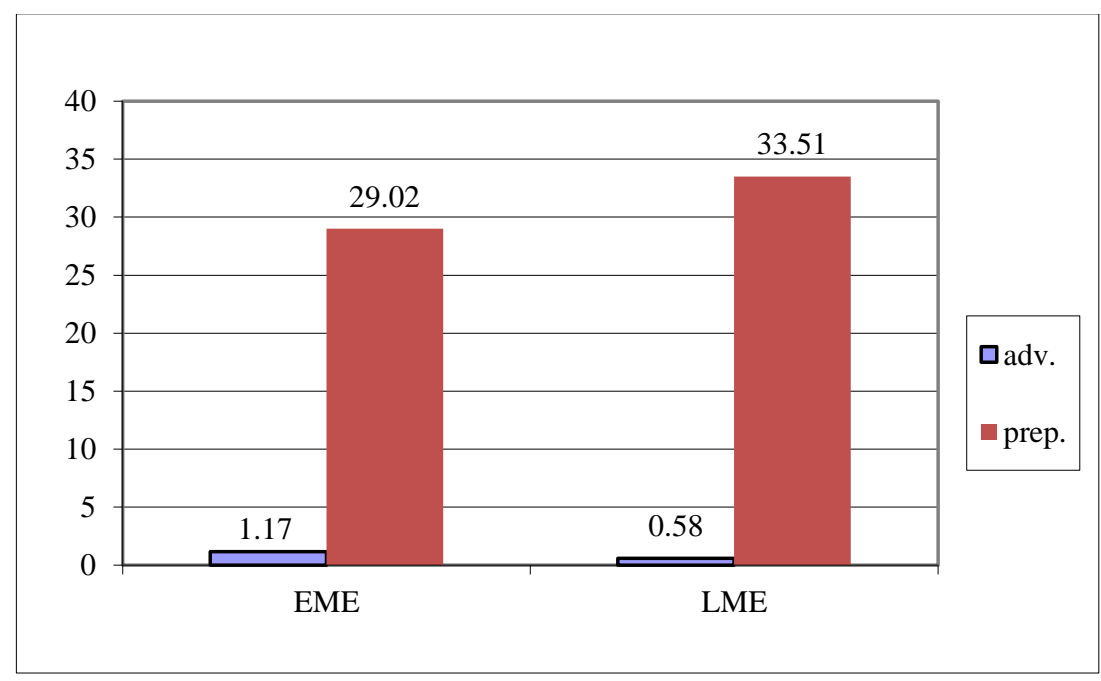

Figure 9. Early and Late Middle English bitwēne: relative frequency per 100,000 words 
As demonstrated in Figure 9, bitwēne functions almost exclusively as a preposition in both Early and Late Middle English prose. Its adverbial function is even about twice less frequent in the latter period. Moreover, the relative frequency of the use of bitwene as a preposition steadily grows between Early and Late Middle English. On the basis of those observations of the behaviour of bitwène in the analysed Middle English prose, it can be claimed that bitwēne is highly grammaticalised in prose representing both examined periods. Those global results are also validated by the distribution of the tokens of bitwene functioning as a preposition or as an adverb in every dialect and in every particular text employing bitwēne.

\subsection{Grammaticalisation of bitwix(en)}

The analysed Middle English prose texts employ 390 occurrences of bitwix(en) (Ciszek-Kiliszewska 2017: 176). Their distribution in Early and Late Middle English prose is presented in Table 10.

Table 10. The tokens of bitwix(en) in Middle English prose

\begin{tabular}{|c|c|c|c|}
\hline Period & $\begin{array}{c}\text { Number of all } \\
\text { words }\end{array}$ & Number of tokens & $\begin{array}{c}\text { Relative frequency per } \\
\mathbf{1 0 0 , 0 0 0} \text { words }\end{array}$ \\
\hline EME & 599,583 & 50 & 8.34 \\
\hline LME & $1,900,729$ & 340 & 17.89 \\
\hline ME & $2,500,312$ & 390 & 15.60 \\
\hline
\end{tabular}

The normalised frequency per 100,000 words shows that the relative use of bitwix(en) grows considerably between the two analysed subperiods. In Late Middle English it is about twice higher than in Early Middle English.

Interestingly, bitwix(en) appears in only two out of the 21 analysed Early Middle English texts (cf. bitwēne above). Twelfth-Cent. Homilies in MS Vespasian representing the Kentish dialect include as many as 46 instances of bitwix(e) while Twelfth-Cent. Homilies preserved in MS Bodley 343 representing the Southern dialect contain four cases of bitwix(e). All the recorded tokens of Early Middle English bitwix(en) function as prepositions. Thus, the relative frequency of the preposition bitwix(en) equals the general relative frequency of bitwix(en) in the subperiod, i.e., 8.34 per 100,000 words (see Table 10 above).

The Late Middle English prose texts exhibit by and large a higher number of recorded tokens of bitwix(en) in comparison to the Early Middle English texts. Table 11 (in the Appendix) shows their textual distribution of the occurrences according to the syntactic function. 
The table shows that the adverbial use of bitwix(en) in the Late Middle English prose is only marginal. Figure 10 highlights the LME data normalised to the relative frequencies per 100,000 words.

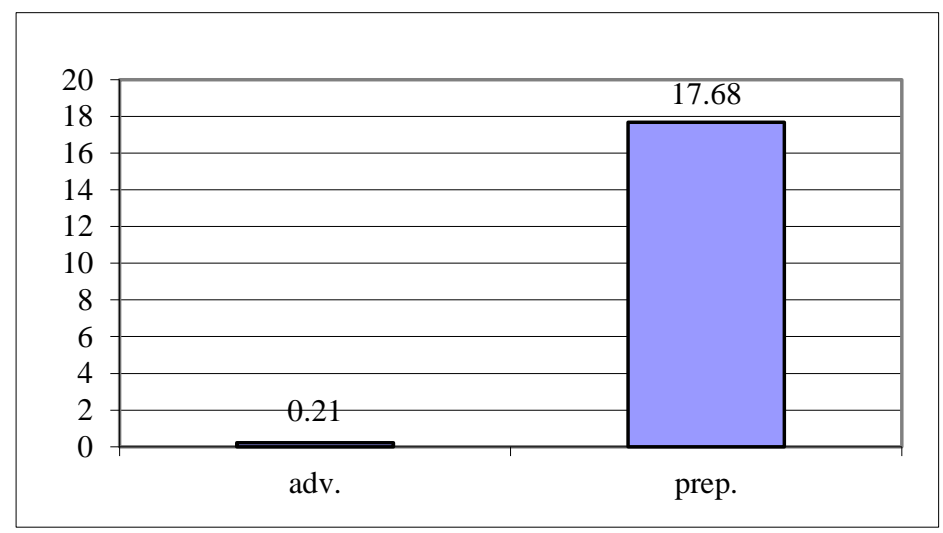

Figure 10. Late Middle English bitwix(en): relative frequency per 100,000 words

Figure 11 combines the Early and Late Middle English data concerning bitwix(en).

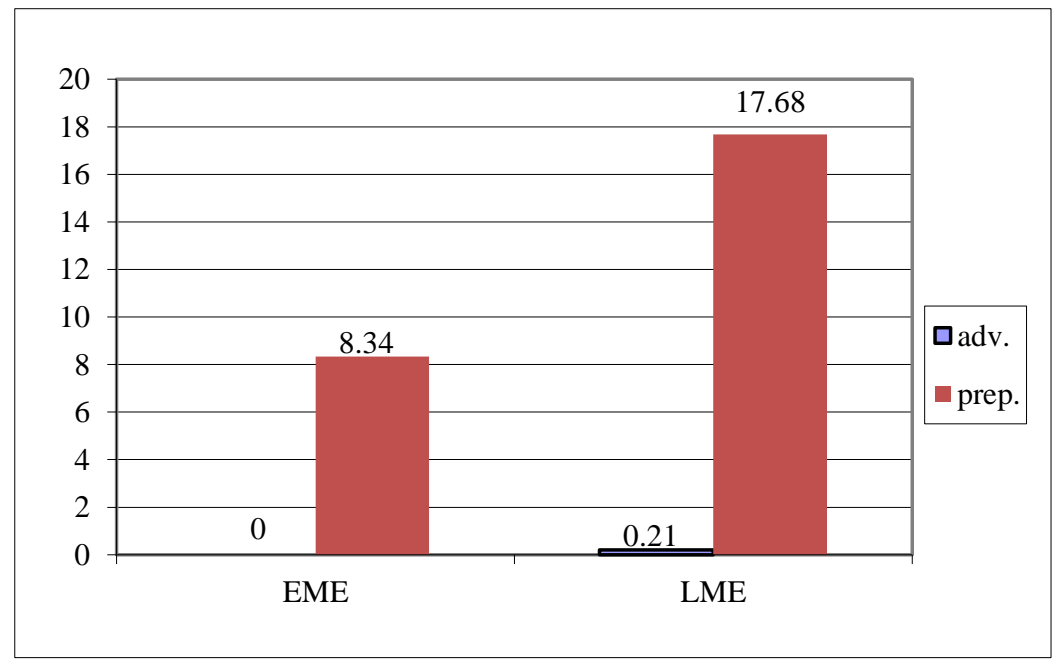

Figure 11. Early and Late Middle English bitwix(en): relative frequency per 100,000 words

As can be seen, the word functions exclusively as a preposition in Early Middle English prose and almost exclusively so in Late Middle English prose. Moreover, the relative frequency of use of the preposition bitwix(en) increases about twice in the latter subperiod of Middle English. Hence, it can be claimed that bitwix(en) is highly grammaticalised not only in Late but already in Early Middle English prose. Those observations are also confirmed by the distribution of the 
occurrences of bitwix(en) functioning as a preposition or as an adverb in every dialect and in every specific text including bitwix(en).

\section{Conclusions}

The aim of the present study was to investigate the degree of grammaticalisation of four selected complex adverbs with the prefix $b e-$, ME $b i-/ b e-$, in the Middle English period. The examined words shared some structural, functional, etymological and semantic characteristics and included behind, beneath, between and betwixt, i.e., ME bihīnde(n), binēthe(n), bitwēne and bitwix(en). Moreover, all analysed complex adverbs originally emerged in the process of grammaticalisation from the preposition and adverb $b \bar{l}$ (big) 'about' developing into the prefix $b i-/ b e$ - and respective adverbs with the originally locative sense. The analysis was conducted on the basis of Middle English prose texts, which are unbiased by some poetic devices and thus closer to the spoken natural language. For that purpose 56 specially selected texts (c. 2.5 million words) from the Innsbruck Corpus of Middle English Prose (Markus 2010) were examined. The degree of grammaticalisation was tested on the basis of the proportion between their use with the adverbial and with the prepositional function.

The grammaticalisation of the four examined words, i.e., bihinde(n), binèthe(n), bitwēne and bitwix(en) exhibits three different degrees. Bitwēne and bitwix(en) are similarly highly grammaticalised in both Early and Late Middle English prose. It is manifested by either no cases or only a marginal frequency of their use with the adverbial function in both examined subperiods. Bihinde(n) is less grammaticalised showing the dominating adverbial use in Early Middle English prose, which, however, changes to the prepositional function being employed more frequently than the adverbial one in the Late Middle English prose. ME binethe $(n)$ is the least grammaticalised. It is used as an adverb relatively about twice more frequently than as a preposition in prose representing both Middle English subperiods. Additionally, the scrutiny of every individual text and dialect and the behaviour of the analysed four lexemes there provided insight into some interesting peculiarities concerning the degree of grammaticalisation as viewed from those perspectives. While the degrees of grammaticalisation estimated for bitweene and bitwix(en) in Early and Late Middle English are also valid for every dialect and every single analysed text, bihinde(n) and binēthe(n) display a somewhat smaller textual and dialectal compliance. 


\section{References}

Dictionaries and electronic databases

ARCHER $=$ A Representative Corpus of Historical English Registers. 1992-1993. Douglas Biber and Edward Finegan (compilers). Manchester: University of Manchester.

DOE = Dictionary of Old English. 2016. Angus Cameron, Ashley Crandell Amos, Antonette diPaolo Healey et al. (eds.), Dictionary of Old English: A to H online. Toronto: University of Toronto.

DOEC = Dictionary of Old English Corpus. [1981] 2009. Antonette diPaolo Healey with John Price Wilkin and Xin Xiang (compilers), The Dictionary of Old English Corpus Web Corpus, Tei-P5 Conformant Version. Toronto: University of Toronto Center for Medieval Studies DOE Project. eLALME = An Electronic Version of A Linguistic Atlas of Late Mediaeval English (version 1.0). 2013- Michael Benskin, Margaret Laing, Vasilis Karaiskos and Keith Williamson. Edinburgh: University of Edinburgh. Available from: http://www.lel.ed.ac.uk/ihd/elalme/elalme.html [Accessed: 14 ${ }^{\text {th }}$ June 2017]

HC $=$ Helsinki Corpus of English Texts. 1991. Matti Rissanen, Merja Kytö, Leena Kahlas-Tarkka, Matti Kilpiö, Saara Nevanlinna, Irma Taavitsainen, Terttu Nevalainen and Helena RaumolinBrunberg (compilers). Helsinki: Department of Modern Languages, University of Helsinki.

$I C=$ Innsbruck Corpus of Middle English Prose (CD-ROM version 2.4.). 2010. Manfred Markus (compiler). Innsbruck: University of Innsbruck.

LAEME = A Linguistic Atlas of Early Middle English, 1150-1325 (version 2.1). 2008- . Margaret Laing (compiler). Electronic text corpus with accompanying software, index of sources and theoretical introduction (with Roger Lass). Edinburgh: The University of Edinburgh. Available from: http://www.lel.ed.ac.uk /ihd/laeme1/laeme1.html [Accessed: 14 ${ }^{\text {th }}$ June 2017]

LALME = A Linguistic Atlas of Late Mediaeval English. 1986. Angus McIntosh et al. (eds.). A Linguistic Atlas of Late Mediaeval English. 4 vols. Aberdeen: Aberdeen University Press.

$M E D=$ Middle English Dictionary. 1952-2002. Hans Kurath, Sherman M. Kuhn and Robert E. Lewis (eds.). Ann Arbor: University of Michigan Press; London and Oxford: Oxford University Press. Available from: http://quod.lib.umich.edu/m/med/ [Accessed: $14^{\text {th }}$ June 2017]

MEC = Middle English Compendium: The Middle English Dictionary, A Hyper Bibliography of Middle English Prose and Verse, a Corpus of Middle English Prose and Verse. 2001- . Frances McSparran (University of Michigan) (compiler). Humanities Text Initiative. Available from: http://ets.umdl.umich.edu/m/ mec/ [Accessed: 14 ${ }^{\text {th }}$ June 2017]

$O E D=$ Oxford English Dictionary (first published as A New English Dictionary on Historical Principles). 1884- . James A. H. Murray, Henry Bradley, William A. Craigie, and Charles T. Onions (eds.). Oxford: Clarendon Press, 1884-1928. Supplement, Robert W. Burchfield (ed.), 1972-1986. 2nd ed., J. A. Simpson and E. S. C. Weiner (eds.), Oxford: Oxford University Press, 1989. 3rd edition in progress, 2000- . Available from: http://oed.com [Accessed: 14 ${ }^{\text {th }}$ June 2017]

Secondary sources

Ciszek-Kiliszewska, Ewa. 2014. Middle English preposition twēn(e), Studia Anglica Posnaniensia 49(3). 91-111.

Ciszek-Kiliszewska, Ewa. 2017a. Dynamics of use of Middle English bitwix(en). In Andrzej Łęcki, Jerzy Nykiel and Ireneusz Kida (eds.) Current Developments in English Historical Linguistics: Studies in Honour of Rafat Molencki. Katowice: Wydawnictwo Uniwersytetu Śląskiego. 214226.

Ciszek-Kiliszewska, Ewa. 2017b. Middle English prepositions and adverbs with the prefix $b e$ - in prose texts: A study in their semantics, dialectology and frequency. Frankfurt am Main, Bern, Bruxelles, New York, Oxford, Warszawa and Wien: Peter Lang. 
Esquibel, Joanna and Wojtyś, Anna. 2012. Devil aka Satan: An enemy or fiend? On the rivalry between the familiar and the foreign in early English, Token: A Journal of English Linguistics 1. 97-113.

Hopper, Paul and Elizabeth Closs Traugott. 2003. Grammaticalization. ( $2^{\text {nd }}$ edition). Cambridge: Cambridge University Press.

Hotta, Ryuichi. 2014. Betwixt and between: The ebb and flow of their historical variants. Journal of the Faculty of Letters: Language, Literature and Culture. 2014. 17-36.

Iglesias-Rábade, Luis. 2011. Semantic erosion of Middle English prepositions. Frankfurt/Main: Peter Lang.

Kahlas-Tarkka, Lena. 2010. Preposition + TIME (+THAT): Exploring Temporal Connectives in Early English. In Osamu Imahayashi, Yoshiyuki Nakao and Michiko Ogura (eds.), Aspects of the History of English Language and Literature: Selected Papers Read at SHELL 2009. Hiroshima: Peter Lang. 309-319.

Kitson, Peter. 1993. Geographical variation in Old English prepositions and the location of Ælfric's and other literary dialects. English Studies 74: 1-50.

Kuryłowicz, Jerzy. 1965. The evolution of grammatical categories, Diogenes 51. 55-71.

Molencki, Rafał. 2003. The etymology and development of the conjunction $a$ s in Middle English, Linguistica Silesiana 24: 25-39.

Molencki, Rafał. 2005. On the syntactic and semantic development of after in medieval English. In Marcin Krygier and Liliana Sikorska (eds.), Naked wordes in Englissh. Medieval English Mirror 2. Frankfurt/Main: Peter Lang. 47-67.

Molencki, Rafał. 2007a. On the rise of the temporal preposition/conjunction before. In Marcin Krygier and Liliana Sikorska (eds.), To make his Englissh sweete upon his tonge. Medieval English Mirror 3. Frankfurt/Main: Peter Lang. 37-54.

Molencki, Rafał. 2007b. Rozwój diachroniczny before i after w języku angielskim [A diachronic evolution of before and after in English]. In Andrzej Łyda (ed.), Przestrzenie języka [Language spaces]. Katowice: Wyższa Szkoła Zarządzania Marketingowego i Języków Obcych. 10-24.

Molencki, Rafał. 2007c. The evolution of since in medieval English. In Ursula Lenker and Anneli Meurman-Solin (eds.), Connectives in the history of English. Amsterdam and Philadelphia: John Benjamins. 97-113.

Molencki, Rafał. 2008. The rise of because in Middle English, In Masachiyo Amano, Michiko Ogura and Masayuki Ohkado (eds.), Historical Englishes in varieties of texts and contexts. Frankfurt/Main: Peter Lang. 201-216.

Molencki, Rafał. 2011a. New prepositions and subordinating conjunctions of Romance origin in Middle English. In Jacek Fisiak and Magdalena Bator (eds.), Foreign influences on Medieval English (Studies in English Medieval Language and Literature 28). Frankfurt/Main: Peter Lang. 9-24.

Molencki, Rafał. 2011b. The evolution of forward in Mediaeval English, In Renate Bauer and Ulrike Krischke (eds.), More than words. English lexicography past and present. Frankfurt/Main and New York: Peter Lang. 225-244.

Molencki, Rafał. 2012. Casual conjunctions in Mediaeval English: A corpus-based study of grammaticalisation. Katowice: Uniwersytet Śląski.

Rissanen, Matti. 2000. Paths of loan-word grammaticalization: The case of according to. In Christiane Dalton-Puffer and Nikolaus Ritt (eds.), Words: Structure, meaning, function. A festschrift for Dieter Kastovsky. Berlin and New York: De Gruyter Mouton. 117-130.

Rissanen, Matti. 2004. Grammaticalization from side to side: On the development of beside( $s)$. In Hans Lindkvist and Christian Mair (eds.), Corpus approaches to grammaticalization in English. Amsterdam: John Benjamins. 151-170.

Rissanen, Matti. 2005. The development of till and until in English. In Jacek Fisiak and Hye-Kyung Kang (eds.), Recent trends in Medieval English language and literature in honour of Young-Bae Park. Vol. I. Seoul, Thaehaksa. 75-92. 
Rissanen, Matti. 2007. From $o p$ to till: Early loss of an adverbial subordinator. In Ursula Lenker and Anneli Meurman-Solin (eds.), Connectives in the history of English. Amsterdam and Philadelphia: John Benjamins. 61-75.

Wełna, Jerzy. 2013. The regional aspects of the distribution of nouns in -ling in Middle English. In Jacek Fisiak and Magdalena Bator (eds.), Historical English Word Formation and Semantics. (Warsaw Studies in English Language and Literature). Frankfurt am Main: Peter Lang Verlag. 489-501.

Wełna, Jerzy. 2015. In search of the missing link, or how OE macode became ModE made. In Brian Lowrey and Fabienne Toupin (eds.), Studies in linguistic variation and change: from Old to Middle English. Cambridge: Cambridge Scholars Publishing. 90-105. 


\section{Appendix}

Table 2. Bihīnde(n) in Early Middle English prose

\begin{tabular}{|c|c|c|c|c|}
\hline Text & $\begin{array}{l}\text { Number of } \\
\text { all words }\end{array}$ & $\begin{array}{c}\text { Number of } \\
\text { bihinde(n) }\end{array}$ & ADV & PREP \\
\hline \multicolumn{5}{|l|}{ West Midland } \\
\hline Wohunge of Ure Lauerd & 4,090 & - & - & - \\
\hline Seinte Marherete (MS Royal) & 8,818 & - & - & - \\
\hline St. Julian (MS Bodley) & 7,576 & 3 & 2 & 1 \\
\hline St. Julian (MS Royal) & 7,002 & 1 & 1 & - \\
\hline Hali Meidenhad (Bodley) & 9,193 & - & - & - \\
\hline Hali Meidenhad (MS Titus) & 9,238 & - & - & - \\
\hline Hali Meidhad (crit) & 9,200 & - & - & - \\
\hline Sawles Warde & 4,937 & 1 & 1 & - \\
\hline Ancrene Riwle (MS Titus) & 62,713 & 6 & 5 & 1 \\
\hline Ancrene Wisse (MS Corp-C) & 75,185 & 9 & 7 & 2 \\
\hline St. Katherine (MS Royal) & 11,804 & - & - & - \\
\hline Ancrene Riwle (Gon-Ca) & 30,591 & 4 & 2 & 2 \\
\hline Seinte Marherete (MS Bodley) & 8,877 & - & - & - \\
\hline \multicolumn{5}{|l|}{ Southern } \\
\hline $\begin{array}{l}\text { Twelfth-Cent. Homilies } \\
\text { (MS Bodley 343) }\end{array}$ & 27,517 & - & - & - \\
\hline History of the Holy Rood-tree & 7,456 & - & - & - \\
\hline Ancrene Riwle (MS Nero) & 75,407 & 7 & 5 & 2 \\
\hline $\begin{array}{c}\text { Old English Homilies of the } 12 \text { th } \\
\text { century (Trinity Coll. Cbr. MS. } \\
\text { B. 14.52) }\end{array}$ & 42,304 & 1 & 1 & - \\
\hline \multicolumn{5}{|l|}{ Kentish } \\
\hline $\begin{array}{c}\text { Twelfth-Cent. Homilies (MS } \\
\text { Vespasian) }\end{array}$ & 60,982 & - & - & - \\
\hline Kentish Sermons & 3,996 & - & - & - \\
\hline $\begin{array}{c}\text { Dan Michel, Ayenbite of Inwyt, or } \\
\text { Remorse of Conscience }\end{array}$ & 104,128 & 18 & 11 & 7 \\
\hline \multicolumn{5}{|l|}{ East Midland } \\
\hline Vices and Virtues & 28,569 & - & - & - \\
\hline
\end{tabular}




\begin{tabular}{|c|c|c|c|c|}
\hline Total & 599,583 & 50 & 35 & 15 \\
\hline
\end{tabular}

Table 3. Bihinde(n) in Late Middle English prose

\begin{tabular}{|c|c|c|c|c|}
\hline Text & \begin{tabular}{|c|} 
Number of all \\
words
\end{tabular} & $\begin{array}{l}\text { Number of } \\
\text { bihīnde(n) }\end{array}$ & ADV & PREP \\
\hline \multicolumn{5}{|l|}{ West Midland } \\
\hline \multirow{2}{*}{$\begin{array}{c}\text { Brut, or The Chronicles of } \\
\text { England }\end{array}$} & 105,947 & 2 & - & 2 \\
\hline & 116,492 & 20 & 3 & 17 \\
\hline $\begin{array}{c}\text { Three Middle English Sermons } \\
\text { (MS Wor F. } 10 ; 2^{\text {nd }} \text { and } 3^{\text {rd }} \\
\text { sermon) }\end{array}$ & 24,408 & 2 & 1 & 1 \\
\hline De Imitatione Christi & 49,382 & 3 & 1 & 2 \\
\hline Speculum Sacerdotale & 110,513 & 7 & 3 & 4 \\
\hline \multicolumn{5}{|l|}{ Southern } \\
\hline $\begin{array}{c}\text { The Book of the Knight of La } \\
\text { Tour-Landry }\end{array}$ & 80,078 & 3 & - & 3 \\
\hline $\begin{array}{c}\text { Two Fifteenth-Century Cookery } \\
\text { Books (MS Harley 279) }\end{array}$ & 25,809 & 5 & 1 & 4 \\
\hline \multicolumn{5}{|l|}{ Kentish } \\
\hline Merlin & 22,0635 & 43 & 26 & 17 \\
\hline \multicolumn{5}{|l|}{ East Midland } \\
\hline Ancrene Riwle (MS Pepys) & 77,272 & 4 & 3 & 1 \\
\hline The Gospel of Nicodemus & 13,836 & - & - & - \\
\hline Pepysian Gospel Harmony & 40,333 & 6 & 3 & 3 \\
\hline John Metham: Christmas Day [1] & 592 & - & - & - \\
\hline John Metham: Christmas Day [2] & 353 & - & - & - \\
\hline Paston Letters & 277,954 & 20 & 15 & 5 \\
\hline Fistula in ano & 40,066 & 3 & - & 3 \\
\hline Adam and Eve & 9,058 & 1 & 1 & - \\
\hline $\begin{array}{c}\text { Richard Misyn: The Mending of } \\
\text { Life }\end{array}$ & 12,668 & - & - & - \\
\hline Richard Misyn: The Fire of Love & 51,169 & 6 & 6 & - \\
\hline
\end{tabular}




\begin{tabular}{|c|c|c|c|c|}
\hline $\begin{array}{c}\text { Secreta Secretorum (MS Royal } \\
\text { 18.A.7) }\end{array}$ & 16,441 & 1 & 1 & - \\
\hline $\begin{array}{c}\text { Julian of Norwich: Revelations of } \\
\text { Divine Love (Shorter Version) }\end{array}$ & 15,151 & - & - & - \\
\hline $\begin{array}{l}\text { John Trevisa: Methodius, The } \\
\text { Bygynnyng of the World }\end{array}$ & 3,674 & - & - & - \\
\hline $\begin{array}{l}\text { John Mandeville: Mandeville's } \\
\text { Travels (MS. Bodl. e Mus. 116) }\end{array}$ & 25,393 & 2 & 1 & 1 \\
\hline Speculum Christiani & 31,427 & 2 & 1 & 1 \\
\hline Richard Lavynham: A Litil Tretys & 12,119 & - & - & - \\
\hline Pater Noster of Richard Ermyte & 28,855 & - & - & - \\
\hline John Metham: Days of the Moon & 2,981 & - & - & - \\
\hline \multirow{2}{*}{ John Metham: Palmistry } & 5,633 & 2 & - & 2 \\
\hline & 5,374 & - & - & - \\
\hline John Metham: Physiognomy & 9,144 & 2 & - & 2 \\
\hline $\begin{array}{c}\text { John Capgrave's Lives of St. } \\
\text { Augustine }\end{array}$ & 58,585 & 6 & 3 & 3 \\
\hline $\begin{array}{c}\text { John Capgrave's Chronicles, } \\
\text { Abbreviation of }\end{array}$ & 87,590 & 6 & 2 & 4 \\
\hline Cely Letters & 90,411 & 13 & 3 & 10 \\
\hline $\begin{array}{c}\text { Spheres and Planets, in The Book } \\
\text { of Quintessence }\end{array}$ & 320 & - & - & - \\
\hline Book of Quintessence & 9,830 & 1 & 1 & - \\
\hline $\begin{array}{l}\text { Secreta Secretorum (MS Lambeth } \\
\text { 501) }\end{array}$ & 32,911 & 5 & 4 & 1 \\
\hline $\begin{array}{c}\text { Agnus Castus. A Middle English } \\
\text { Herbal }\end{array}$ & 27,412 & - & - & - \\
\hline \multicolumn{5}{|l|}{ Northern } \\
\hline \multirow{2}{*}{ Alphabet of Tales } & 90,250 & 13 & 4 & 9 \\
\hline & 90,663 & 11 & 2 & 9 \\
\hline Total & $1,900,729$ & 189 & 85 & 104 \\
\hline
\end{tabular}


Table 5. Binēthe(n) in Early Middle English prose

\begin{tabular}{|c|c|c|c|c|}
\hline Text & \begin{tabular}{|c|}
$\begin{array}{c}\text { Number of all } \\
\text { words }\end{array}$ \\
\end{tabular} & $\begin{array}{l}\text { Number of } \\
\text { binēthe(n) }\end{array}$ & ADV & PREP \\
\hline \multicolumn{5}{|l|}{ West Midland } \\
\hline Wohunge of Ure Lauerd & 4,090 & - & - & - \\
\hline Seinte Marherete (MS Royal) & 8,818 & 1 & 1 & - \\
\hline St. Julian (MS Bodley) & 7,576 & 1 & 1 & - \\
\hline St. Julian (MS Royal) & 7,002 & 1 & 1 & - \\
\hline Hali Meidenhad (Bodley) & 9,193 & - & - & - \\
\hline Hali Meidenhad (MS Titus) & 9,238 & - & - & - \\
\hline Hali Meidhad (crit) & 9,200 & - & - & - \\
\hline Sawles Warde & 4,937 & - & - & - \\
\hline Ancrene Riwle (MS Titus) & 62,713 & 2 & 1 & 1 \\
\hline Ancrene Wisse (MS Corp-C) & 75,185 & 2 & 1 & 1 \\
\hline St. Katherine (MS Royal) & 11,804 & - & - & - \\
\hline Ancrene Riwle (Gon-Ca) & 30,591 & 1 & - & 1 \\
\hline Seinte Marherete (MS Bodley) & 8,877 & 1 & 1 & - \\
\hline \multicolumn{5}{|l|}{ Southern } \\
\hline $\begin{array}{c}\text { Twelfth-Cent. Homilies (MS } \\
\text { Bodley 343) }\end{array}$ & 27,517 & 1 & - & 1 \\
\hline History of the Holy Rood-tree & 7,456 & - & - & - \\
\hline Ancrene Riwle (MS Nero) & 75,407 & 2 & 1 & 1 \\
\hline $\begin{array}{c}\text { Old English Homilies of the 12th } \\
\text { century (Trinity Coll. Cbr. MS. B. } \\
14.52 \text { ) }\end{array}$ & 42,304 & 2 & - & 2 \\
\hline \multicolumn{5}{|l|}{ Kentish } \\
\hline $\begin{array}{l}\text { Twelfth-Cent. Homilies (MS } \\
\text { Vespasian) }\end{array}$ & 60,982 & - & - & - \\
\hline Kentish Sermons & 3,996 & - & - & - \\
\hline $\begin{array}{c}\text { Dan Michel, Ayenbite of Inwyt, or } \\
\text { Remorse of Conscience }\end{array}$ & 104,128 & 10 & 8 & 2 \\
\hline East Midland & & & & \\
\hline
\end{tabular}




\begin{tabular}{|c|c|c|c|c|}
\hline Vices and Virtues & 28,569 & 2 & 2 & - \\
\hline Total & 599,583 & 26 & 17 & 9 \\
\hline
\end{tabular}

Table 6. Binēthe(n) in Late Middle English prose

\begin{tabular}{|c|c|c|c|c|}
\hline Text & \begin{tabular}{|c|}
$\begin{array}{c}\text { Number of all } \\
\text { words }\end{array}$ \\
\end{tabular} & $\begin{array}{c}\text { Number of } \\
\text { binēthe(n) }\end{array}$ & ADV & PREP \\
\hline \multicolumn{5}{|l|}{ West Midland } \\
\hline \multirow{2}{*}{$\begin{array}{c}\text { Brut, or The Chronicles of } \\
\text { England }\end{array}$} & 105,947 & - & - & - \\
\hline & 116,492 & 3 & 1 & 2 \\
\hline $\begin{array}{l}\text { Three Middle English Sermons } \\
\text { (MS Wor F. } 10 ; 2^{\text {nd }} \text { and } 3^{\text {rd }} \\
\text { sermon) }\end{array}$ & 24,408 & - & - & - \\
\hline De Imitatione Christi & 49,382 & 5 & 4 & 1 \\
\hline Speculum Sacerdotale & 110,513 & - & - & - \\
\hline \multicolumn{5}{|l|}{ Southern } \\
\hline $\begin{array}{c}\text { The Book of the Knight of La } \\
\text { Tour-Landry }\end{array}$ & 80,078 & - & - & - \\
\hline $\begin{array}{c}\text { Two Fifteenth-Century Cookery } \\
\text { Books (MS Harley 279) }\end{array}$ & 25,809 & 4 & 2 & 2 \\
\hline \multicolumn{5}{|l|}{ Kentish } \\
\hline Merlin & 22,0635 & 10 & 6 & 4 \\
\hline \multicolumn{5}{|l|}{ East Midland } \\
\hline Ancrene Riwle (MS Pepys) & 77,272 & 2 & 1 & 1 \\
\hline The Gospel of Nicodemus & 13,836 & - & - & - \\
\hline Pepysian Gospel Harmony & 40,333 & - & - & - \\
\hline John Metham: Christmas Day [1] & 592 & - & - & - \\
\hline John Metham: Christmas Day [2] & 353 & - & - & - \\
\hline Paston Letters & 277,954 & 1 & - & 1 \\
\hline Fistula in ano & 40,066 & 3 & 3 & - \\
\hline Adam and Eve & 9,058 & - & - & - \\
\hline
\end{tabular}




\begin{tabular}{|c|c|c|c|c|}
\hline $\begin{array}{l}\text { Richard Misyn: The Mending of } \\
\text { Life }\end{array}$ & 12,668 & - & - & - \\
\hline Richard Misyn: The Fire of Love & 51,169 & 1 & 1 & - \\
\hline $\begin{array}{c}\text { Secreta Secretorum (MS Royal } \\
\text { 18.A.7) }\end{array}$ & 16,441 & - & - & - \\
\hline $\begin{array}{c}\text { Julian of Norwich: Revelations of } \\
\text { Divine Love (Shorter Version) }\end{array}$ & 15,151 & 3 & - & 3 \\
\hline $\begin{array}{c}\text { John Trevisa: Methodius, The } \\
\text { Bygynnyng of the World }\end{array}$ & 3,674 & - & - & - \\
\hline $\begin{array}{l}\text { John Mandeville: Mandeville's } \\
\text { Travels (MS. Bodl. e Mus. 116) }\end{array}$ & 25,393 & - & - & - \\
\hline Speculum Christiani & 31,427 & - & - & - \\
\hline Richard Lavynham: A Litil Tretys & 12,119 & - & - & - \\
\hline Pater Noster of Richard Ermyte & 28,855 & - & - & - \\
\hline John Metham: Days of the Moon & 2,981 & - & - & - \\
\hline \multirow{2}{*}{ John Metham: Palmistry } & 5,633 & - & - & - \\
\hline & 5,374 & - & - & - \\
\hline John Metham: Physiognomy & 9,144 & 3 & 3 & - \\
\hline $\begin{array}{c}\text { John Capgrave's Lives of St. } \\
\text { Augustine }\end{array}$ & 58,585 & 4 & 3 & 1 \\
\hline $\begin{array}{c}\text { John Capgrave's Chronicles, } \\
\text { Abbreviation of }\end{array}$ & 87,590 & 1 & 1 & - \\
\hline Cely Letters & 90,411 & 1 & - & 1 \\
\hline $\begin{array}{l}\text { Spheres and Planets, in The Book } \\
\text { of Quintessence }\end{array}$ & 320 & - & - & - \\
\hline Book of Quintessence & 9,830 & 3 & 3 & - \\
\hline $\begin{array}{l}\text { Secreta Secretorum } \\
\text { (MS Lambeth 501) }\end{array}$ & 32,911 & 2 & 2 & - \\
\hline $\begin{array}{c}\text { Agnus Castus. A Middle English } \\
\text { Herbal }\end{array}$ & 27,412 & 2 & 2 & - \\
\hline \multicolumn{5}{|l|}{ Northern } \\
\hline \multirow{2}{*}{ Alphabet of Tales } & 90,250 & - & - & - \\
\hline & 90,663 & 1 & 1 & - \\
\hline Total & $1,900,729$ & 49 & 33 & 16 \\
\hline
\end{tabular}


Table 8. Bitwēne in Early Middle English prose

\begin{tabular}{|c|c|c|c|c|}
\hline Text & \begin{tabular}{|c|}
$\begin{array}{c}\text { Number of all } \\
\text { words }\end{array}$ \\
\end{tabular} & $\begin{array}{c}\text { Number of } \\
\text { bitwēne }\end{array}$ & ADV & PREP \\
\hline \multicolumn{5}{|l|}{ West Midland } \\
\hline Wohunge of Ure Lauerd & 4,090 & - & - & - \\
\hline Seinte Marherete (MS Royal) & 8,818 & - & - & - \\
\hline St. Julian (MS Bodley) & 7,576 & 1 & - & 1 \\
\hline St. Julian (MS Royal) & 7,002 & - & - & - \\
\hline Hali Meidenhad (Bodley) & 9,193 & 1 & - & 1 \\
\hline Hali Meidenhad (MS Titus) & 9,238 & 1 & - & 1 \\
\hline Hali Meidhad (crit) & 9,200 & 1 & - & 1 \\
\hline Sawles Warde & 4,937 & - & - & - \\
\hline Ancrene Riwle (MS Titus) & 62,713 & 28 & 1 & 27 \\
\hline Ancrene Wisse (MS Corp-C) & 75,185 & 31 & 3 & 28 \\
\hline St. Katherine (MS Royal) & 11,804 & 1 & - & 1 \\
\hline Ancrene Riwle (Gon-Ca) & 30,591 & 21 & 1 & 20 \\
\hline Seinte Marherete (MS Bodley) & 8,877 & - & - & - \\
\hline \multicolumn{5}{|l|}{ Southern } \\
\hline $\begin{array}{l}\text { Twelfth-Cent. Homilies (MS } \\
\text { Bodley 343) }\end{array}$ & 27,517 & 3 & - & 3 \\
\hline History of the Holy Rood-tree & 7,456 & 6 & - & 6 \\
\hline Ancrene Riwle (MS Nero) & 75,407 & 30 & 2 & 28 \\
\hline $\begin{array}{c}\text { Old English Homilies of the 12th } \\
\text { century (Trinity Coll. Cbr. MS. B. } \\
14.52 \text { ) }\end{array}$ & 42,304 & 7 & - & 7 \\
\hline \multicolumn{5}{|l|}{ Kentish } \\
\hline $\begin{array}{c}\text { Twelfth-Cent. Homilies (MS } \\
\text { Vespasian) }\end{array}$ & 60,982 & 7 & - & 7 \\
\hline Kentish Sermons & 3,996 & 1 & - & 1 \\
\hline $\begin{array}{c}\text { Dan Michel, Ayenbite of Inwyt, or } \\
\text { Remorse of Conscience }\end{array}$ & 104,128 & 37 & - & 37 \\
\hline East Midland & & & & \\
\hline
\end{tabular}




\begin{tabular}{|c|c|c|c|c|}
\hline Vices and Virtues & 28,569 & 5 & - & 5 \\
\hline Total & 599,583 & 181 & 7 & 174 \\
\hline
\end{tabular}

Table 9. Bitwēne in Late Middle English prose

\begin{tabular}{|c|c|c|c|c|}
\hline Text & $\begin{array}{c}\text { Number of all } \\
\text { words }\end{array}$ & $\begin{array}{c}\text { Number of } \\
\text { bitwēne }\end{array}$ & ADV & PREP \\
\hline \multicolumn{5}{|l|}{ West Midland } \\
\hline \multirow{2}{*}{$\begin{array}{c}\text { Brut, or The Chronicles of } \\
\text { England }\end{array}$} & 105,947 & 115 & - & 115 \\
\hline & 116,492 & 126 & 2 & 124 \\
\hline $\begin{array}{c}\text { Three Middle English Sermons } \\
\text { (MS Wor F. 10; } 2^{\text {nd }} \text { and } 3^{\text {rd }} \\
\text { sermon) }\end{array}$ & 24,408 & - & - & - \\
\hline De Imitatione Christi & 49,382 & 7 & 1 & 6 \\
\hline Speculum Sacerdotale & 110,513 & 24 & - & 24 \\
\hline \multicolumn{5}{|l|}{ Southern } \\
\hline $\begin{array}{c}\text { The Book of the Knight of La } \\
\text { Tour-Landry }\end{array}$ & 80,078 & 32 & 2 & 30 \\
\hline $\begin{array}{c}\text { Two Fifteenth-Century Cookery } \\
\text { Books (MS Harley 279) }\end{array}$ & 25,809 & 5 & - & 5 \\
\hline \multicolumn{5}{|l|}{ Kentish } \\
\hline Merlin & 22,0635 & 135 & 1 & 134 \\
\hline \multicolumn{5}{|l|}{ East Midland } \\
\hline Ancrene Riwle (MS Pepys) & 77,272 & 26 & 1 & 25 \\
\hline The Gospel of Nicodemus & 13,836 & 5 & - & 5 \\
\hline Pepysian Gospel Harmony & 40,333 & 2 & - & 2 \\
\hline John Metham: Christmas Day [1] & 592 & - & - & - \\
\hline John Metham: Christmas Day [2] & 353 & - & - & - \\
\hline Paston Letters & 277,954 & 91 & 2 & 89 \\
\hline Fistula in ano & 40,066 & 1 & - & 1 \\
\hline Adam and Eve & 9,058 & 2 & - & 2 \\
\hline $\begin{array}{c}\text { Richard Misyn: The Mending of } \\
\text { Life }\end{array}$ & 12,668 & - & - & - \\
\hline
\end{tabular}




\begin{tabular}{|c|c|c|c|c|}
\hline Richard Misyn: The Fire of Love & 51,169 & - & - & - \\
\hline $\begin{array}{c}\text { Secreta Secretorum (MS Royal } \\
\text { 18.A.7) }\end{array}$ & 16,441 & - & - & - \\
\hline $\begin{array}{c}\text { Julian of Norwich: Revelations of } \\
\text { Divine Love (Shorter Version) }\end{array}$ & 15,151 & - & - & - \\
\hline $\begin{array}{l}\text { John Trevisa: Methodius, The } \\
\text { Bygynnyng of the World }\end{array}$ & 3,674 & - & - & - \\
\hline $\begin{array}{l}\text { John Mandeville: Mandeville's } \\
\text { Travels (MS. Bodl. e Mus. 116) }\end{array}$ & 25,393 & 8 & - & 8 \\
\hline Speculum Christiani & 31,427 & 5 & - & 5 \\
\hline Richard Lavynham: A Litil Tretys & 12,119 & 3 & - & 3 \\
\hline Pater Noster of Richard Ermyte & 28,855 & 4 & - & 4 \\
\hline John Metham: Days of the Moon & 2,981 & 1 & - & 1 \\
\hline \multirow{2}{*}{ John Metham: Palmistry } & 5,633 & 13 & - & 13 \\
\hline & 5,374 & 13 & - & 13 \\
\hline John Metham: Physiognomy & 9,144 & 6 & - & 6 \\
\hline $\begin{array}{c}\text { John Capgrave's Lives of St. } \\
\text { Augustine }\end{array}$ & 58,585 & - & - & - \\
\hline $\begin{array}{c}\text { John Capgrave's Chronicles, } \\
\text { Abbreviation of } \\
\end{array}$ & 87,590 & - & - & - \\
\hline Cely Letters & 90,411 & 13 & 2 & 11 \\
\hline $\begin{array}{c}\text { Spheres and Planets, in The Book } \\
\text { of Quintessence }\end{array}$ & 320 & - & - & - \\
\hline Book of Quintessence & 9,830 & 1 & - & 1 \\
\hline $\begin{array}{l}\text { Secreta Secretorum (MS Lambeth } \\
501 \text { ) }\end{array}$ & 32,911 & 10 & - & 10 \\
\hline $\begin{array}{c}\text { Agnus Castus. A Middle English } \\
\text { Herbal }\end{array}$ & 27,412 & - & - & - \\
\hline \multicolumn{5}{|l|}{ Northern } \\
\hline \multirow{2}{*}{ Alphabet of Tales } & 90,250 & - & - & - \\
\hline & 90,663 & - & - & - \\
\hline Total & $1,900,729$ & 648 & 11 & 637 \\
\hline
\end{tabular}


Table 11. Bitwix(en) in Late Middle English prose

\begin{tabular}{|c|c|c|c|c|}
\hline Text & \begin{tabular}{|c|}
$\begin{array}{c}\text { Number of all } \\
\text { words }\end{array}$ \\
\end{tabular} & $\begin{array}{c}\text { Number of } \\
\text { bitwix(en) }\end{array}$ & ADV & PREP \\
\hline \multicolumn{5}{|l|}{ West Midland } \\
\hline \multirow{2}{*}{$\begin{array}{c}\text { Brut, or The Chronicles of } \\
\text { England }\end{array}$} & 105,947 & 1 & - & 1 \\
\hline & 116,492 & 2 & - & 2 \\
\hline $\begin{array}{c}\text { Three Middle English Sermons } \\
\text { (MS Wor F. } 10 ; 2^{\text {nd }} \text { and } 3^{\text {rd }} \\
\text { sermon) }\end{array}$ & 24,408 & 8 & - & 8 \\
\hline De Imitatione Christi & 49,382 & - & - & - \\
\hline Speculum Sacerdotale & 110,513 & 8 & - & 8 \\
\hline \multicolumn{5}{|l|}{ Southern } \\
\hline $\begin{array}{c}\text { The Book of the Knight of La } \\
\text { Tour-Landry }\end{array}$ & 80,078 & 1 & - & 1 \\
\hline $\begin{array}{c}\text { Two Fifteenth-Century Cookery } \\
\text { Books (MS Harley 279) }\end{array}$ & 25,809 & - & - & - \\
\hline \multicolumn{5}{|l|}{ Kentish } \\
\hline Merlin & 22,0635 & - & - & - \\
\hline \multicolumn{5}{|l|}{ East Midland } \\
\hline Ancrene Riwle (MS Pepys) & 77,272 & 6 & - & 6 \\
\hline The Gospel of Nicodemus & 13,836 & 3 & - & 3 \\
\hline Pepysian Gospel Harmony & 40,333 & 3 & - & 3 \\
\hline John Metham: Christmas Day [1] & 592 & - & - & - \\
\hline John Metham: Christmas Day [2] & 353 & - & - & - \\
\hline Paston Letters & 277,954 & 104 & 1 & 103 \\
\hline Fistula in ano & 40,066 & - & - & - \\
\hline Adam and Eve & 9,058 & - & - & - \\
\hline $\begin{array}{c}\text { Richard Misyn: The Mending of } \\
\text { Life }\end{array}$ & 12,668 & 2 & - & 2 \\
\hline Richard Misyn: The Fire of Love & 51,169 & 14 & 1 & 13 \\
\hline $\begin{array}{c}\text { Secreta Secretorum (MS Royal } \\
\text { 18.A.7) }\end{array}$ & 16,441 & 1 & - & 1 \\
\hline $\begin{array}{c}\text { Julian of Norwich: Revelations of } \\
\text { Divine Love (Shorter Version) }\end{array}$ & 15,151 & 4 & - & 4 \\
\hline
\end{tabular}




\begin{tabular}{|c|c|c|c|c|}
\hline $\begin{array}{c}\text { John Trevisa: Methodius, The } \\
\text { Bygynnyng of the World }\end{array}$ & 3,674 & 3 & 1 & 2 \\
\hline $\begin{array}{l}\text { John Mandeville: Mandeville's } \\
\text { Travels (MS. Bodl. e Mus. 116) }\end{array}$ & 25,393 & - & - & - \\
\hline Speculum Christiani & 31,427 & - & - & - \\
\hline Richard Lavynham: A Litil Tretys & 12,119 & 2 & - & 2 \\
\hline Pater Noster of Richard Ermyte & 28,855 & - & - & - \\
\hline John Metham: Days of the Moon & 2,981 & - & - & - \\
\hline \multirow{2}{*}{ John Metham: Palmistry } & 5,633 & - & - & - \\
\hline & 5,374 & - & - & - \\
\hline John Metham: Physiognomy & 9,144 & - & - & - \\
\hline $\begin{array}{c}\text { John Capgrave's Lives of St. } \\
\text { Augustine }\end{array}$ & 58,585 & 25 & 1 & 24 \\
\hline $\begin{array}{c}\text { John Capgrave's Chronicles, } \\
\text { Abbreviation of }\end{array}$ & 87,590 & 85 & - & 85 \\
\hline Cely Letters & 90,411 & 25 & - & 25 \\
\hline $\begin{array}{c}\text { Spheres and Planets, in The Book } \\
\text { of Quintessence }\end{array}$ & 320 & - & - & - \\
\hline Book of Quintessence & 9,830 & 1 & - & 1 \\
\hline \begin{tabular}{|c|} 
Secreta Secretorum (MS Lambeth \\
501 )
\end{tabular} & 32,911 & 1 & - & 1 \\
\hline $\begin{array}{c}\text { Agnus Castus. A Middle English } \\
\text { Herbal }\end{array}$ & 27,412 & - & - & - \\
\hline \multicolumn{5}{|l|}{ Northern } \\
\hline \multirow{2}{*}{ Alphabet of Tales } & 90,250 & 26 & - & 26 \\
\hline & 90,663 & 15 & - & 15 \\
\hline Total & $1,900,729$ & 340 & 4 & 336 \\
\hline
\end{tabular}

